\title{
KORELASI ANTARA WAKTU, RUANG DAN ENERGI DALAM PENGUATAN KETAHANAN ENERGI NASIONAL
}

\author{
Herman Agustiawan \\ Dewan Energi Nasional (DEN)
}

\begin{abstract}
This paper attempts to bring up the sense of vital energy in people's lives. Without a thorough planning, energy could lead a problem to wildlife as a country's energy security and also could threaten the national security of countries concerned. Choosing a source of energy for at least three factors that must be observed, namely security of supply, pricing (harga keekonomian), and the environment that are closely associated with the dimension of time and space.
\end{abstract}

Key Words: Energy, Energy Security

\section{PENDAHULUAN}

Waktu, ruang dan energi adalah tiga parameter yang universal bagi kehidupan manusia. Tidak seorangpun manusia dapat bertahan hidup tanpa mengkonsumsi salah satu dari ketiganya. Agar manusia bisa bertahan hidup, mansia harus mengkonsumsi energi (listrik, bahan bakar, mekanik, panas, dan sebagainya), kapanpun dan dimanapun mereka berada.

Waktu, ruang dan energi merupakan tiga besaran utama dalam ilmu Fisika, yang satu dengan lainnya saling berkorelasi. Korelasi antara waktu dan ruang bersifat permanen dan menghasilkan indeks keterkaitan terhadap energi yang dikonsumsinya. Sebagai contoh, jarak antara dua buah titik yang tetap dapat kita tempuh dalam waktu atau energi yang lebih sedikit, jika efisiensi penggunaan energinya tinggi. Sebaliknya, jarak yang sama dapat kita tempuh dalam waktu atau energi yang lebih banyak, jika efisiensinya rendah. Demikian seterusnya; kombinasi dari masing-masing besaran tersebut akan saling berkorelasi membentuk satu paket korelasi yang baru dan unik.

Mengapa unik? Setiap hari kita memiliki waktu selama 24 jam, dan kepada kita diberikan kebebasan untuk menggunakannya. Jika waktu tersebut kita gunakan, maka sesaat setelah waktu tersebut dikonsumsi, 
ketersediaan waktu tersebut menjadi habis atau musnah (vanished) - tidak dapat diulangi! Ini berarti bahwa manusia tidak diperbolehkan kembali ke masa lampau. Oleh karena setelah dikonsumsi waktu akan habis, maka fisik kita pun tidak mungkin berada di dua tempat pada saat yang sama, meskipun kita diperbolehkan berpindah-pindah tempat. Dengan kata lain, kepada manusia hanya diberikan satu-pasangan tempat-dan-waktu, one-toone-relationship.

Berbeda halnya dengan waktu dan ruang, agar dapat bertahan hidup manusia harus mengkonsumsi energi berulang-ulang, baik itu dalam bentuk jenis, jumlah, maupun kualitasnya. Disadari atau tidak, manusia akan secara otomatis mengkonsumsi waktu, ruang dan energi pada saat bersamaan. Jumlah energi yang dikonsumsi oleh seseorang mencerminkan tingkat pendidikan dan kesehatannya. Seorang siswa SMP pada umumnya akan membutuhkan lebih banyak energi (misal: listrik dan BBM) dibandingkan dengan anak SD. Demikian pula halnya dengan siswa SMA, mereka mengkonsumsi lebih banyak energi dibandingkan anak SMP.

Tidak dapat dipungkiri bahwa kesehatan pun sangat erat kaitannya dengan pola hidup. Mereka yang menjaga keseimbangan antara makanan, olah raga, hiburan, rekreasi dan sebagainya, akan mengkonsumsi energi listrik dan bahan bakar lebih banyak dibandingkan bila mereka tidak melakukan pola hidup yang demikian. Balita dan manula akan membutuhkan fasilitas dan pelayanan kesehatan yang lebih banyak ketimbang mereka yang berusia di antaranya. Lebih jauh lagi, dapat dibuktikan bahwa bangsa di dunia yang sudah maju dan rakyatnya sejahtera serta mandiri, tingkat mortalitasnya rendah.

Orang yang sering berpindah tempat (misalnya karena profesinya) dalam waktu yang relatif singkat, mencerminkan bahwa keberadaan orang tersebut diperlukan atau bermanfaat bagi orang lain. Orang yang demikian pasti akan mengkonsumsi lebih banyak energi karena harus memindahmindahkan fisiknya dalam waktu yang singkat. Barangkali tidak seratus persen salah kalau dikatakan, "Semakin orang bermanfaat bagi orang lain, semakin banyak energi yang dikonsumsinya." Sementara, mereka yang masih pada usia produktif namun karena satu dan lain hal hanya mengkonsumsi energi dalam jumlah yang kecil, maka secara umum keberadaan mereka kurang bermanfaat bagi kebanyakan orang.

Oleh karena manusia harus mengkonsumsi energi, maka kepada mereka dikenakan tiga syarat perlu (necessary condition) yaitu ketersediaan (availability), kemudahan memperoleh (accessibility) dan kemampuan membeli (affordability).

Availability. Agar tidak terjadi kelangkaan pasokan energi maka ketersediaan energi, baik itu dalam bentuk cadangan sumber daya energi di sisi hulu maupun dalam bentuk cadangan operasional di sisi hilir, termasuk proses pengolahan di antaranya, mutlak diperlukan. Di beberapa negara 
yang relatif tidak memiliki sumber daya energi, seperti Jepang dan Korea, ketersediaan dapat diartikan dalam bentuk infrastruktur pengolahan dan cadangan operasional yang dijamin pemenuhannya sesuai dengan dinamika perubahan laju konsumsi. Di Indonesia, guna menjaga keamanan jaminan pasokan, laju konsumsi harus disesuaikan dengan dinamika dari pertumbuhan penduduk, pertumbuhan ekonomi, dan target peningkatan konsumsi energi perkapita. Dinamika laju konsumsi idealnya tercermin dalam penciptaan lapangan pekerjaan, peningkatan pendidikan, kesehatan dan kesejahteraan bangsa.

Accessibility. Kemudahan dalam mengakses energi dicirikan oleh tersedianya sarana dan prasarana, baik itu di sektor ketenagalistrikan maupun di sektor transportasi (jalan, pelabuhan laut dan udara, dan lainlain).

Affordability. Kemampuan atau daya beli masyarakat terhadap harga dan jumlah energi yang dibutuhkannya. Daya beli tidak berarti bahwa harga energi harus selalu disubsidi, akan tetapi bisa juga karena masyarakat memiliki income sedemikian hingga memungkinkan mereka memiliki daya beli sejumlah energi yang dibutuhkannya sesuai dengan harga keekonomian.

Selain sebagai indikator pendidikan dan kesehatan di atas, besarnya konsumsi energi per kapita juga mencerminkan tingkat kesejahteraan dan kemandirian seseorang. Mereka yang bermanfaat bagi kebanyakan orang umumnya sudah mandiri dalam hal pemenuhan kebutuhan energi bagi dirinya. Dalam konteks berbangsa dan bernegara, ketiga faktor tersebut akan menentukan seberapa kuat ketahanan energi (energi security) suatu bangsa. Dan pada akhirnya jumlah konsumsi energi perkapita tersebut akan mencerminkan tingkat kesehatan, pendidikan, kesejahteraan dan kemandirian suatu bangsa.

Di samping ketiga faktor pada necessary condition di atas, ketahanan energi nasional juga ditentukan oleh sebagian kecil masyarakat yang oleh karena kehidupan atau profesinya memerlukan bukan hanya jumlah dan jenis energi saja, tetapi juga kualitas energi. Pemenuhan konsumsi energi bagi mereka yang demikian bisa dikategorikan dalam syarat kesempurnaan/kecukupan (sufficient condition). Berbeda dengan mereka yang masih berkutat dengan kebutuhan pokok, kelompok manusia yang terakhir ini dapat dikatakan telah memasuki kategori konsumsi lanjut; mereka-mereka ini mengkonsumsi energi secara efisien, efektif dan bersih.

\section{KONDISI KETERSEDIAAN DAN KEBUTUHAN ENERGI}

Seperti diketahui bahwa, ketersediaan sumber daya energi dalam jumlah yang relatif banyak dari minyak, gas dan batubara, serta sumber energi baru terbarukan telah memposisikan Indonesia secara global sebagai 
salah satu negara penghasil sumber energi utama. Indonesia merupakan salah satu pemasok utama gas alam cair (LNG) dan produsen batu bara terbesar kedelapan di dunia.

Potensi kekayaan minyak bumi di Indonesia diperkirakan sebesar 56,6 miliar barel, dan sementara sumber daya gas bumi 334,5 TSCF (termasuk CBM), namun kenyataannya pada saat ini cadangan terbukti minyak nasional hanya 3,7 miliar barel dan gas hanya 112,4 TSCF. Sedangkan sumber daya CBM, yang diperkirakan mencapai 453 TCF, masih utuh belum dieksplorasi karena persyaratan teknologi dan biaya investasi yang tinggi.

Sumber daya energi batubara di Indonesia sekitar 104,5 milyar ton dengan cadangan mencapai 5,5 miliar ton. Produksi batubara domestik sekitar 230 juta ton/tahun, yang sebagian besar diekspor karena beberapa alasan. Ke depan, kebutuhan batubara diperkirakan melampaui minyak sebagai sumber energi primer domestik, khususnya untuk pembangkit listrik.

Bahan bakar alternatif yang juga penting bagi Indonesia adalah bahan bakar nabati (BBN). BBN memiliki potensi sebagai sumber energi di sektor transportasi. Namun, beberapa hambatan seperti ketersedian lahan, teknologi budidaya dan pengolahan, serta nilai keekonomian yang masih rendah, telah menyebabkan BBN masih belum dapat masuk ke dalam skala komersial secara massif.

Pengembangan sumber daya energi terbarukan, walaupun jumlahnya relatif banyak, namun belum bisa dimanfaatkan secara optimal dan perlu waktu yang lama untuk memenuhi kebutuhan energi nasional yang sangat besar. Hal ini disebabkan karakteristik yang melekat pada sumber daya energi terbarukan, antara lain skalanya yang kecil (low-density), lokasinya yang spesifik, konsistensi ketersediaannya yang bergantung pada alam, dan harganya relatif mahal.

Tabel 1. Energy Mix di Indonesia (dalam persen)

\begin{tabular}{|l|c|c|}
\hline \multirow{2}{*}{ Energi } & \multicolumn{2}{c|}{$\mathbf{2 0 2 5}$} \\
\cline { 2 - 3 } & BAU & SO \\
\hline Minyak & 41,7 & $\mathbf{2 6 , 2}$ \\
\hline Gas & 20,6 & 30,6 \\
\hline Batubara & 34,6 & 32,7 \\
\hline Hydropower & 1,9 & 2,4 \\
\hline Panas Bumi & $\mathbf{1 , 1}$ & 3,8 \\
\hline $\begin{array}{l}\text { Enerbi Baru dan } \\
\text { Terbarukan }\end{array}$ & $\mathbf{0 , 1}$ & 4,4 \\
\hline
\end{tabular}

Keterangan: BAU (business as usual), SO (skenario optimistis).

Sumber: ESDM 
Sumber energi lain yang menjanjikan adalah energi nuklir. Ditinjau dari aspek ketahanan pasokan energi dalam negeri ke depan, energi nuklir sebenarnya merupakan komponen penting dalam bauran energi nasional. Tenaga nuklir dapat mengurangi persoalan energi bukan hanya untuk masa depan (2050), tetapi dalam waktu 10 sampai 20 tahun mendatang. Hal ini guna sesegera mungkin untuk mengimbangi kemampuan pasokan dari sumber energi terbarukan (kapasitas dan keekonomian), pemenuhan defisit listrik saat ini, jumlah dan pertumbuhan penduduk yang tinggi, serta target pertumbuhan ekonomi yang harus dicapai.

Namun, sampai saat ini solusi terhadap bagaimana mempercepat pemenuhan kebutuhan listrik bangsa ini masih menemui banyak hambatan. Di Indonesia, konsumsi listrik per kapita pada tahun 2010 baru sekitar 620 kWh yang di pasok melalui pembangkit dengan kapasitas sekitar 35 Giga Watt. Bandingkan dengan Jepang yang pada tahun 2006 saja konsumsi listrik per kapitanya sudah mencapai $7667 \mathrm{kWh}$, Amerika Serikat di tahun yang sama konsumsi per kapita mencapai $14.117 \mathrm{kWh}$.

Pada tahun 2025 diharapkan konsumsi listrik per kapita di Indonesia akan meningkat menjadi sekitar $1900 \mathrm{kWh}$. Untuk memenuhi konsumsi per kapita tersebut, kapasitas pembangkit yang diperlukan pada 2025 berkisar antara 115-145 GW, yang berarti Indonesia harus membangun pembangkit sekitar 6-7 GW per tahun. Dan kebutuhan ini akan terus meningkat sejalan dengan pertumbuhan penduduk dan ekonomi menjadi sekitar 7.500 kWh per kapita pada tahun 2050, dengan kapasitas pembangkit sekitar 500 Giga Watt.

Kurangnya pasokan dan kehandalan listrik telah menyebabkan terganggunya perkembangan industri. Sehingga merupakan hambatan bagi pertumbuhan ekonomi yang artinya akan menambah jumlah pengangguran, rendahnya tingkat pendidikan, kesehatan dan pada akhirnya kesejahteraan rakyat.

Saat ini, sebagian besar pasokan energi yang dikonsumsi di dalam negeri berasal dari sumber daya energi Migas (berkisar 70\% hingga 80\%). Di sektor ketenagalistrikan penggunaan BBM pun masih cukup tinggi, terutama di luar pulau Jawa. Sementara di sektor transportasi, minimnya kendaraan publik yang massal telah menyebabkan penggunaan BBM bersubsidi menjadi tidak terkendali. Rata-rata pertumbuhan mobil pribadi lebih tinggi dari angkutan umum dan barang. Sementara pertumbuhan sepeda motor jauh lebih tinggi dari semua jenis kendaraan bermotor dan mencapai 87.136.0oo unit pada tahun 2009 ( $73 \%$ dari jumlah total).

Seperti kita ketahui bahwa harga premium di dalam negeri dijual di bawah harga keekonomiannya. Untuk itu pemerintah harus mengeluarkan anggaran subsidi BBM yang terus meningkat, yang pada tahun 2009 sebesar Rp42,9 triliun menjadi Rp89,2 triliun pada 2010. Yang sangat 
memprihatinkan adalah bahwa mereka yang menerima subsidi justru kelompok rumah tangga dengan penghasilan perbulan $25 \%$ tertinggi, yaitu sebesar $77 \%$. Sedangkan kelompok rumah tangga dengan penghasilan perbulan $25 \%$ terendah hanya menerima susidi sebesar $15 \%$ saja.

Demikian halnya dengan beban subsidi listrik yang pada tahun 2009 sebesar Rp40,5 triliun naik menjadi Rp57,6 triliun pada tahun 2010. Hal ini disebabkan karena masih tingginya penggunaan BBM, yaitu sebesar 25,6\% sebagai energi input untuk pembangkit listrik. Di samping itu, sasaran penerima subsidi listrik pun masih belum tepat sasaran, yaitu sebesar 33,8\% dari pelanggan Golongan Atas ( $\mathrm{S}_{3}, \mathrm{R}_{3}, \mathrm{~B}_{3}$ dan $\left.\mathrm{I}_{3}\right)$.

Dari gambaran di atas terlihat bahwa ketahanan energi nasional saat ini telah dan sedang mengalami tantangan berat yang dapat berubah menjadi ancaman bila tidak segera diatasi. Kerentanan ini diperparah dengan membanjirnya produk Cina yang menyebabkan industri dalam negeri tidak berdaya. Semua ini terjadi sebagai akibat dari kurang realistisnya kebijakan termasuk implementasinya sehingga dapat mengakibatkan energy insecurity.

Kebijakan energi yang tidak memperhatikan dimensi waktu dan ruang akan mengakibatkan pemborosan sumber daya energi yang sangat berharga. Pusat beban listrik dan kegiatan perekonomian yang tekonsentrasi di Pulau Jawa, sedangkan sumber daya energi pokok terletak jauh di Kalimantan, menuntut kebijakan penggunaan jenis sumber energi untuk memperhatikan kondisi geografis sebagai negara kepulauan.

Keterlambatan pembangunan infrastruktur listrik, jalan dan pelabuhan (laut dan udara) telah menghambat investasi, dan merupakan faktor pendorong terhadap ketidak-efisienan dalam penggunaan sumber energi. Pembangunan infrastruktur energi harus mampu mengatasi laju konsumsi sebagai akibat dari pertumbuhan penduduk dan ekonomi. Sehingga dimensi waktu dan ruang akan terus menjadi parameter utama di dalam pengelolaan energi nasional ke depan.

\section{KERENTANAN (VULNERABILITIES)}

Kebijakan dan berbagai peraturan turunan di bidang energi yang tidak didasarkan atas permasalahan yang ada (groundless and unrealistic energy policy $\mathcal{E}$ regulation) akan menyebabkan kerentanan yang pada akhirnya menciptakan energy insecurity. Kerentanaan tersebut dapat berupa salah satu atau kombinasi dari berbagai kejadian, seperti bencana alam, kelangkaan bahan bakar, penggunaan BBM yang berlebihan dalam bauran energi, harga BBM yang terlalu murah, bauran energi yang tidak proporsional, kehandalan dan efesiensi yang rendah dari fasilitas energi (pembangkit listrik dan kilang minyak), kegiatan teroris, dan sebagainya. 
Kevakuman karena adanya isu-isu yang berkembang yang menyimpang dari perencanaan dan rencana tindak (action plan) semula juga dapat membuang waktu dan memboroskan sumber daya energi yang sangat berharga. Biaya ekonomi (economic cost) yang harus dibayar jauh lebih besar dan tidak mustahil berbagai kerentanan yang ada tersebut akan mengubah dari semula energy insecurity menjadi national insecurity.

Tabel 2. Konsumsi Minyak berdasarkan Sektor Ekonomi (dalam persen)

\begin{tabular}{|c|c|c|c|c|c|c|}
\hline Tahun & Industri & Transportasi & $\begin{array}{c}\text { Rumah } \\
\text { Tangga }\end{array}$ & Komersial & $\begin{array}{c}\text { Lain- } \\
\text { lain }\end{array}$ & Total \\
\hline 1990 & 21,9 & 44,0 & 22,8 & 1,4 & 10,0 & 100 \\
\hline 1991 & 21,8 & 44,7 & 21,6 & 1,6 & 10,2 & 100 \\
\hline 1992 & 23,0 & 45,2 & 20,1 & 1,9 & 9,8 & 100 \\
\hline 1993 & 24,0 & 44,2 & 18,8 & 2,3 & 10,8 & 100 \\
\hline 1994 & 24,7 & 43,1 & 18,4 & 2,4 & 11,4 & 100 \\
\hline 1995 & 25,1 & 43,1 & 17,4 & 2,4 & 12,0 & 100 \\
\hline 1996 & 23,8 & 44,4 & 16,6 & 2,5 & 12,6 & 100 \\
\hline 1997 & 23,6 & 44,6 & 16,9 & 2,5 & 12,5 & 100 \\
\hline 1998 & 25,1 & 45,4 & 18,0 & 2,1 & 9,4 & 100 \\
\hline 1999 & 27,5 & 44,3 & 17,5 & 2,0 & 8,7 & 100 \\
\hline 2000 & 27,7 & 44,6 & 17,2 & 2,0 & 8,5 & 100 \\
\hline 2001 & 27,4 & 45,0 & 17,3 & 2,0 & 8,4 & 100 \\
\hline 2002 & 26,6 & 45,4 & 17,6 & 1,9 & 8,4 & 100 \\
\hline 2003 & 24,0 & 47,4 & 18,2 & 1,9 & 8,5 & 100 \\
\hline 2004 & 25,0 & 47,9 & 17,2 & 1,8 & 8,1 & 100 \\
\hline
\end{tabular}

Sumber: ESDM, 2008

\section{TANTANGAN (CHALLENGES)}

Dinamika tantangan terhadap pemenuhan kebutuhan energi domestik yang terus meningkat guna mengejar target pertumbuhan ekonomi tahunan dan menekan pertumbuhan penduduk telah menambah sisi unik terhadap perumusaan kebijakan energi. Pada saat yang sama kebijakan energi juga sedapat mungkin harus meminimalkan ketergantungan domestik terhadap impor minyak dari luar. Hal ini terutama karena ketidakseimbangan antara laju konsumsi dalam negeri relatif terhadap produksi dan cadangan yang diperkirakan hanya sampai dua dekade saja. Sehingga, kekurangan pasokan di dalam negeri telah dan akan menyebabkan semakin beratnya peningkatan ketergantungan terhadap asing.

Namun demikian, gambaran ketersediaan minyak di dunia (global outlook) masih tetap volatile dan unstable. Tetapi, sumber minyak bagaimanapun terbatas, dan meskipun kepastian habisannya masih belum 
pasti, namun minyak pada akhirnya akan habis juga. Beberapa faktor lain yang menjadikan beban perekonomian negara sebagai akibat dari ketergantungan dalam negeri terhadap perusahaan minyak asing adalah upaya penghematan cost recovery, termasuk proteksi terhadap industri lokal dan subsidi harga produk minyak guna melindungi masayarakat miskin.

Ketidakseimbangan di atas menyebabkan beban biaya menjadi tinggi ketika harga minyak naik, sehingga sumber daya energi alternatif sebagai pengganti minyak perlu segera dioptimalkan. Pada saat yang sama, konsentrasi penggunaan minyak di sektor transportasi dan pemberian subsidi secara tepat sasaran telah terhambat, sehingga upaya diversifikasi penggunaan bahan bakar sampai saat ini masih belum berhasil.

Saat ini, intensitas energi berada di atas target 1,6\%. Untuk itu pengukuran yang akurat perlu dilakukan guna menghilangkan infrastruktur atau fasilitas energi yang tidak efisien yang menyebabkan pemborosan penggunaan energi, menyeimbangkan bauran energi yang tidak proporsional, serta menajamkan pemanfaatan sumber energi primer dan ketenagalistrikan.

\section{ANCAMAN (THREATS)}

Pemerintah memegang peranan yang vital dalam mencegah dan mengatasi ancaman terhadap ketahanan energi nasional. Pilihan kebijakan mitigasi di bidang energi jatuh ke dalam dua kategori, yaitu Pencegahan dan Perencanaan serta Tanggapan (Prevention E Planning and Response). Serangan yang dilakukan baik oleh manusia maupun alam terhadap cadangan dan infrastruktur energi akan mengancam ketahanan energi. Mitigasi bencana yang terjadi akhir-akhir ini sebagai akibat adanya ancaman terhadap kelancaran pelayanan pasokan energi domestik harus terus diperkuat baik di badan usaha pemerintah maupun swasta.

\section{KESIMPULAN}

Di dalam memilih sumber energi sekurang-kurangnya terdapat tiga faktor yang harus diperhatikan, yaitu ketahanan pasokan (security of supply), keekonomian (economy), dan lingkungan (environment). Ketiga faktor tersebut sangat erat kaitannya dengan dimensi waktu dan ruang. Tanpa memasukan parameter waktu dan ruang, mustahil pengelolaan energi dapat diselesaikan dengan cepat dan benar.

Pengelolaan energi nasional yang belum benar selama ini telah mengakibatkan krisis multi dimensi dalam kehidupan berbangsa dan bernegara. Hal ini karena energi bersama-sama dengan waktu dan ruang merupakan parameter generik kehidupan manusia. Kita tidak punya pilihan 
selain memakan sebanyak, semurah dan secepat mungkin energi guna mendongkrak perekonomian untuk menciptakan lapangan pekerjaan, kesehatan, pendidikan, kesejahteraan dan kemandirian.

\section{DAFTAR PUSTAKA}

Budiarto, Rachmawan. 2011. Kebijakan Energi: Menuju Sistem Energi yang Berkelanjutan. Yogyakarta: Samudera Biru.

Hisyam, Ibrahim. 2009. 40 Tahun Bergelut Energi: BBM, Kapan Selesai?. Jakarta: Bintang Satu Publishing.

Kristoferson, Lars. 1973. "Energy in Society", dimuat dalam Ambio, Vol. 2/No. 6, Energy in Society: A Special Issue (1973).

Kuncoro, Mudrajad, dkk. 2009. Transformasi Pertamina: Dilema antara Orientasi Bisnis \& Pelayanan Publik. Yogyakarta: Galang Press.

Pasqualetti, Martin J. 200o. "Morality, Space and the Power of Wind-Energy Landscapes", dimuat dalam Geographical Review, Vol. 9o/No. 3, July 2000.

Sambodo, Maxensius Tri. 2008. "Energy Sector in Indonesia and Environment Impacts: From Fossil Fuel to Biofuel", dimuat dalam Jurnal Ekonomi dan Pembangunan LIPI, Vol. XVI/No. 1, 2008.

Sanusi, Bachrawi. 1985. Minyak Bumi Mengubah Ekonomi Dunia. Jakarta: Ind-Hill Co.

Syaerazi, M. Kholid. 2009. Di Bawah Bendera Asing: Liberalisasi Industri Migas di Indonesia. Jakarta: $\mathrm{LP}_{3} \mathrm{ES}$.

Yusgiantoro, Purnomo. 200o. Ekonomi Energi: Teori dan Praktik. Jakarta: $\mathrm{LP}_{3} \mathrm{ES}$. 